\title{
PROSPECTS FOR POST-CONFLICT (DE)STABILISATION OF LIBYA
}

\author{
Grzegorz Gil \\ Maria Curie-Skłodowska University in Lublin, \\ Faculty of Political Science, Department of International Relations \\ e-mail: greg.gil@poczta.umcs.lublin.pl
}

\begin{abstract}
During the Arab Spring some MENA regimes were either forced to reform themselves or ousted and replaced by democratic opposition. Amidst half a dozen of cases of this revolution Libya is a specific one. Its Qaddafi era idiosyncrasy fuelled by "oil" state-formation ended up with the destruction of state apparatus and reinvigorated tribal affiliations. The impact of the 2011 events has changed it as a polity but cannot erase the past five decades of neo-patrimonial and repressive rule. Subsequently, the end of the Muammar Qaddafi regime does not promise post-conflict stability as a new Libya has yet to validate its move towards stabilisation or work out a national consensus. This paper identifies three possibilities of the future development of this country (gradual stabilisation, Jihadisation and fragmentation) and considers the likelihood of each in characteristics and the international context.
\end{abstract}

Key words: post-Qaddafi Libya, state-failure, state-building, Islamic State

\section{INTRODUCTION}

During the Arab Spring some MENA regimes were either forced to reform themselves or ousted and replaced by democratic opposition. Amidst half a dozen of cases of this revolution Libya is a specific one. More than three years after the ousting of the Muammar Qaddafi regime, Libya is still a hot topic. It is not stable enough to be labelled a "success story" but there is some normalcy and a political process is under way. As Tripoli fell in August 2011 a former narrative of Libya has been replaced by the unknown - given the average results of previous foreign interventions of that kind outside the western world. The impact of the 2011 foreign intervention has changed it as a polity but cannot erase the past five decades of neo-patrimonial and repressive rule. As it is stated, post-intervention Libya differs in a substantial way from post-conflict Libya. The article aims at presenting the prospects for stabilisation and destabilisation of Libya after Qaddafi 
as a combination of different local forces and international actors engaged. One of essential characteristics of Libya is that it has rarely had a state in the territorial and communal senses of the term. Libya has always been a kind of "a patchwork state" consisting of the often fractious territory and divergent loyalties that have only exacerbated after 2011.

\section{LIBYA’S HISTORICAL BACKGROUND BEFORE QADDAFI}

As Herodotus's Histories depict, by the 5th century, Libya was "wholly sand". ${ }^{1}$ Pre-modern history of Libya was hallmarked by its occupation by the Romans in the first century BC and 600 years later by Arabs who brought Islam to Libya. ${ }^{2}$ Historically, Libya was divided into three separate territories, i.e. Tripolitania in the northwest, Fezzan in the southwest and finally Cyrenaica in the east. ${ }^{3}$ Libyan climate and terrain created major barriers limiting interaction between the three regions. Consequently, the three areas turned their attention and loyalty not towards each other, but towards adjacent countries: Tripolitania towards Tunisia, Fezzan towards Sub-Saharan Africa (esp. Niger) and Cyrenaica towards Egypt.

Each Libyan region was subjected to varying levels of foreign control. In the mid-sixteenth century, Ottomans invaded much of today's Maghreb and joined them into one regency in Tripoli (Eyālet). Yet, in the next two centuries they had lost their influence in favour of local forces which became the semi-independent dynasties with different degrees of autonomy from the Ottoman empire. ${ }^{4}$ Without the foreign patron Tripolitania lapsed and approached the brink of failure but was finally returned to stability with the rule of Ahmed Qaramanli (1711-1745), who introduced a de facto hereditary monarchy and expanded Tripoli's control to Fezzan and Cyrenaica. The Ottomans refrained from investing large numbers of troops. As they focused more on European conflicts, only minimal military contingent was deployed outside Tripolitanian coastal positions. The Qaramanli thereby not only avoided foreign invasion but enlarged the "rogue economy" thanks to employment of corsairs on the main Mediterranean shipping routes (tribute). However, this brought the Qaramanli into open conflict with the United States and Europe as it outlawed piracy and the slave trade in 1815. By 1819, after two Barbary Wars, Tripoli began to disintegrate as it had to give up piracy. ${ }^{5}$

1 D. Vandewalle, A History of Modern Libya, New York 2006, $1^{\text {st }}$ edition, p. 15.

2 The history Libya is covered under six distinct periods: the Ancient period, the Roman era, the Islamic period, Ottoman rule, Italian rule, and the modern period.

3 If to ask Libyans from Tripolitania and Cyrenaica about their standing they look east towards the Middle East or north towards Europe, their identity is thus distinct from African.

4 Ottoman expansion in Maghreb see e.g. J. Illife, Afrykanie. Dzieje kontynentu, Kraków 2011, pp. 195-205.

5 A. Abdullatif Ahmida, The Making of Modern Libya: State Formation, Colonization, and Resistance, Albany 2009, pp. 21-22. 
The Ottomans reasserted their influence over Libya in 1835 but their occupation wasn't complete as they controlled only main cities, coastal areas but almost nothing in Cyrenaica.

The 1884-1885 Berlin Conference did not assign Libya to any of the European powers. Unlike Algeria, Morocco, Tunisia and Egypt, it remained the only "unclaimed" North African territory. In 1911, after the Italo-Turkish War, the three provinces of Libya were brought under Italian colonial control as Italian North Africa. ${ }^{6}$ In response, Libyans organised an insurgency under Omar al-Mukhtar, but this rebellion was finally quelled in $1931 .^{7}$ A few decades later Muammar Qaddafi used this epic story to build up his legitimacy by invoking the spirit of Mukhtar who belonged to the Sufi sect of the Sanusi family. Historically, they always resisted foreign intervention, e.g., by the Ottomans and French colonialists. ${ }^{8}$ The Italians labelled them as jihadists in the same ways that Qaddafi criticised his opponents half a century later.

In the wake of the Second World War Libya was liberated from Italian rule and Great Britain acted as military administration in Tripolitania and Cyrenaica (1943$1949)^{9}$ while the French controlled Fezzan-Ghadames (1943-1951). Eventually, in 1951 the three provinces were united in a federal system as the United Kingdom of Libya under the monarch, King Idris al-Sanusi, because Libyans perceived this as a lesser evil than protracted UN trusteeship. ${ }^{10}$ As the first American ambassador to Libya wrote, "complete independence seemed to many a last resort, an expedient and an experiment to which, with a sigh of relief, nearly everyone could subscribe."11 This reflects the lack of imaginable political structure that could have unified the historical provinces divided by clan loyalties and the desert itself. Even though Tripoli was Libya's capital, King kept his court in Benghazi.

The first decade of Libyan independence was lived without local state-building as the King relied on the British and Americans for military support (agreements from 1953 and 1954). He was even called the "reluctant monarch". In 1963 Libya became a unitary state but Idris failed to create strong state institutions or make necessary reforms. Instead, he banned political parties after the first

${ }^{6}$ Cf. Libya: From Repression to Revolution: A Record of Armed Conflict and International Law Violations, 2011-2013, ed. M. Cheriff Bassiouni, Leiden-Boston 2013, pp. $20-26$ [hereinafter Libya: From Repression].

7 In 1934, Italy adopted the name "Libya" as the official term of the colony (originally used by the Greeks for all of Maghreb, except Egypt).

8 In the sociopolitical vacuum left by the decline of the second Ottoman occupation the Sanusi Order (also known as the Senussiya) emerged as an Islamic (Sufi) revivalism movement. The Order worked hard to create trans-tribal identity and a de-facto state in Cyrenaica by the 1870s.

9 Emirate of Cyrenaica existed between 1949-1951 and consolidated position of the Sanusis with their chief Idris.

10 The proposed Bevin-Sforza plan to establish ten-year trusteeship for the Libyan territories was defeated in the UN General Assembly (1949).

11 Quote from H. Villard, Libya: The New Arab Kingdom of North Africa, Ithaca 1956, p. 33. Cf. Libya: From Repression, p. 41. 
general elections (1952) and re-established religious lodges (zuwaya). We must bear in mind that the traditional social structure in Libya is profoundly defined by tribalism. The country has about 140 influential tribes and clans but only about two dozen wield socio-political authority and vie for power. This tribalism is geographically based (e.g. the biggest tribe - Warfalla in Tripolitania - amounts to nearly 1 million). The modern shape of Libya's basic ethnic characteristics is presented below (see Figure 1). This led to a culture of tribal patronage driven by oil wealth after the latter was discovered in 1959. The monarchy entered Libya onto the road to political exclusion of its citizens and obstruction of local state-building and modernisation. It was described by Dirk Vanderwalle as an "accidental state". ${ }^{2}$

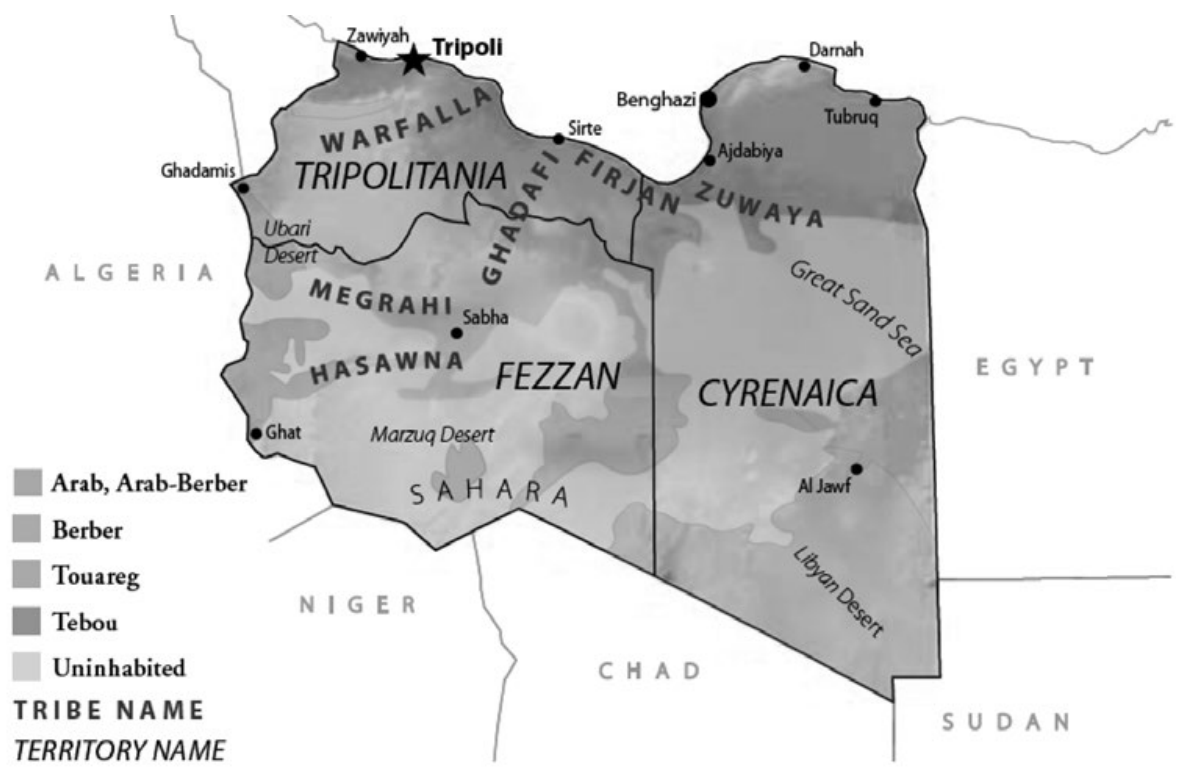

Fig. 1. Modern Libya

Source: courtesy of Stratfor (<http://www.stratfor.com>).

\section{QADDAFI'S STATE-BUILDING AND STATE FAILURE}

Libya began a second experiment in 1969 following Muammar Qaddafi's coup d'etat that ousted the monarch, arguing that he was too dependent on the West. Qaddafi demanded the withdrawal of all British troops and nationalised foreign assets. Yet, the new order resembled the old. In contrast to Idris, Qaddafi referred to Bedouin values like self-reliance and equality, but even if the founding myth of its statehood was different, the final outcome was quite similar: Libya

${ }^{12}$ Cf. D. Vandewalle, A History of Modern Libya, $2^{\text {nd }}$ edition, New York 2012, pp. 43-53. 
suffered from a lack of effective, modern, centralised state institutions under both the King and the "Brotherly Leader." Qaddafi did manage to change Libya as he governed the country with a mixture of Arab nationalism, socialism, eventually embedded in Pan-Africanism. His political survival depended on tribal loyalties as the insignificant Qaddafi tribe had to make alliances with more potent ones (Warfalla, Maqariha). Qaddafi's eccentric "oil state-building” project became possible after Libya joined OPEC in $1962 .{ }^{13}$ To proceed with this course in the first half of the 1970s Libya nationalised the banking sector and the oil industry and reorganized administrative units to break down tribal affiliations. To eradicate tribalism and develop Libyan nationalism he also initiated revolutionary modernisation (social welfare programs) and introduced sharia law. ${ }^{14}$ However, in The Green Book (1976-79) Qaddafi emphasised the importance of family and tribe. ${ }^{15}$ With sky-rocketing prices for Libyan crude oil, Qaddafi stepped up popular revolutionary narrative.

Qaddafi's Libya international legitimacy derived from his Arab neighbours, i.e. Egypt, Syria, Iraq and Sudan with which he shared anti-imperialist sentiments. As a result Libya was added to the American list of enemy regimes. ${ }^{16}$ In 1977, Qaddafi dissolved the Libyan Arab Republic and introduced the Jamahiriya ("a state of the masses") and a system of direct democracy. Since then he had virtually dismantled state institutions and any offspring of civil society. With increased Revolutionary Command Council (RCC) control on the oil sector Qaddafi achieved an economic success and augmented the standard of living; GDP increased from $\$ 3,8$ billion (1969) to $\$ 24,5$ billion (1979). During the first twenty five years of independence Libya's GDP per capita rose two hundred times. ${ }^{17}$ This provided the backbone of Qaddafi's popular legitimacy. In fact, Gaddafi also attempted to preserve the fragile balance of power between the different tribes within his own government and the various state institutions. On the other hand, he created an extensive surveillance system that engaged ten to twenty per cent of Libyans and publicly executed dissidents. This discriminatory policy resulted in tribal tensions as Qaddafi's quasi-socialist and quirky ideology drove Libyans back to older loyalties - clan, tribe and region. ${ }^{18}$

${ }^{13}$ The drilling of oil wells in Libya was first authorised by Petroleum Laws in 1955 and the first oil shipment left from Brega six years later.

${ }^{14}$ Libyan national anthem to 2011 was simply Allahu akbar - God [is] great - and Islam played a political role.

${ }^{15}$ D. Vanderwalle, op. cit., pp. 104-108.

${ }^{16}$ In 1974 Libya embargoed oil export to the United States who supported of Israel.

${ }^{17} \$ 8170$ in 1979 was a level comparable to the wealth of many industrialized states, see e.g. D. Blundy, A. Lycett, Qaddafi and the Libyan Revolution, Boston-Toronto 1987, p. 107.

${ }^{18}$ To counter this trend the Libyan parliament passed a 'code of honor' which enabled the punishment against tribes or clans with the withdrawal of government services if they undermine the regime (1997). 
Although without a formal governmental post, Qaddafi kept firm control over the political process of revolutionary "state-building without the state" as the government was officially detached from the revolution in 1979. In that same year Libya was put on the U.S. list of state sponsors of terrorism. Without a legal code the administration was abusive and arbitrary and served to consolidate some counter-revolutionary activity, inter alia National Front for the Salvation of Libya (NFSL) and Muslim Brotherhood militants. In the course of the early 1980s Libya's annual oil revenues dropped from $\$ 21$ billion to $\$ 5,4$ billion partly due to US economic sanctions and broader international criticism. This forced Qaddafi to liberalize the country in economic (infitah) and political terms but in following next years the further militarisation of the state was undertaken. ${ }^{19}$ In 1992 Libya was struck again, this time by UN sanctions imposed for its alleged role in Pan Am Flight 103 tragedy (UN Security Council Resolution 883 of 1993), further expanded in 1994. The early 1990s saw also an abortive coup by army officers (backed by Warfalla tribe) signalling that his rule was starting to falter. All this shrank Libya's GDP by an estimated $\$ 900$ million and paved the way for economic reforms and privatization that were really unleashed after 2000 with $\mathrm{UN}$ and the United States sanctions lifted (in 2003 and 2004 respectively). ${ }^{20}$ Subsequently, Qaddafi was forced to approach the U.S. and Great Britain and gradually escaped from international isolation (after the Lockerbie trial opened in 2000 and Libya abandoned its nuclear program in 2003). In 2009, after many years of plotting with terrorists and separatist movements, he was officially rehabilitated as a part of "war of terror" and was given the floor at the UN General Assembly. However, political liberalization had not gone hand with hand with economic liberalization. ${ }^{21}$

A decade before the Arab Spring, Clement Henry and Robert Springborg distinguished between two forms of Arab states' political economy and openness to globalization. Using this reasoning, they identified four Arab regime types, among them a "bunker state" and a "bully state". While the former is described by a potential state of war with the society it rules, the latter is more reliant on social legitimacy and is partially ready to carry out reforms to satisfy the populace. Consequently, the leaders of "bunker states" stem from tribal or religious groupings ("bunker") that enable them to control most aspects of social life and repress any notion of disloyalty. In contrast, the "bully" is not as directly oppressive as the "bunker state". In the late-1990s Qaddafi's Libya could be pigeon-holed as a "bunker" (as Algeria, Yemen, Iraq and Syria), while regimes such as Egypt

${ }^{19}$ Qaddafi inter alia allowed the re-introduction of a private sector, eliminated in 1978. See more D. Vanderwalle, $2^{\text {nd }}$ edition, pp. 150-163.

${ }^{20}$ D. Vandewalle, Libya's Revolution in Perspective: 1969-2000, [in:] Libya Since 1969: Qadhafi's Revolution Revisited, ed. D. Vandewalle, New York 2008, p. 42. In 2003, the oil industry has been largely privatized with dominant position of Libyan National Oil Corporation. In 2005 US companies obtained the majority of the new licenses for oil exploration.

${ }^{21}$ Cf. L. Anderson, A Last Resort, an Expedient and an Experiment: Statehood and Sovereignty in Libya, "The Journal of Libyan Studies" 2001, vol. 2, no. 2. 
and Tunisia were "bully" states. ${ }^{22}$ Following the 1969 coup d'état Libyan regime had been forming along clan lines, but the late Qaddafi's reign also approached a "bully state" as this taxonomy is more a matter of degree. However, sooner or later both regimes turned out to be seen as illegitimate in the eyes of people they ruled. ${ }^{23}$ Qaddafi proved it when he finally let the oil-rich state be derailed and much of eastern Libya (the 'old hug' according to him) was neglected in the 2000s due to his economic conceptions. ${ }^{24}$ These years of neglect made many easterners nostalgic for the monarchy. In the broader context the central argument is that local state-building in Libya had been incomplete primarily due to five factors: the colonial legacy, tribalism, Libya's oil bonanza, the political exclusion of its population, and the ignorance of the rulers in capacity building.

Forty-two years after the military coup and three years after normalisation of relations with the US, Qaddafi's reign came to the cruel end. It could even be meteorologically compared to a wind of change as Libyan used to name a hot, dry, dust-bearing desert wind that affects their country in spring and early summer (el-ghibli). On 17 February 2011 the revolution erupted with impetus in eastern Libya (Benghazi) and changed its political landscape. ${ }^{25}$ Qaddafi's power base was located in the west of Libya. This explains why he lost power so easily in Cyrenaica but kept it in the west far longer. Unlike Tunisia or Egypt, Libya was religiously homogeneous and had no strong Islamist groups, but there existed widespread dissatisfaction with corruption and the system of patronage, both exacerbated by $30 \%$ unemployment. In eight months of revolutionary conflict Qaddafi resorted to extreme violence that further increased his illegitimacy in the eyes of both Libyans and the UN, which referred Libya to the International Criminal Court with charges of crimes against humanity. Among the first tribes that disobeyed Qaddafi were Warfalla and Zawiya. While the former undermined the legitimacy of Qaddafi's rule, the latter threatened to interrupt oil exports if Qaddafi continued to suppress the citizens.

The west reacted with a series of sanctions including an arms embargo, travel bans, the establishment of a no-fly zone, and the use of "all necessary means" to protect civilians (UNSC Resolution 1973). ${ }^{26}$ Subsequently, in July 2011 the International Contact Group on Libya formally recognised the main opposition group,

${ }^{22}$ See more C. Henry, R. Springborg, Globalization and the Politics of Development in the Middle East, Cambridge 2001.

${ }^{23}$ In 19961270 men were killed in a Abu Salim massacre but this affected thousands of people, mostly from eastern Libya (this fact has been strictly censored to 2009).

${ }^{24}$ A civil war beckons, "The Economist" <http://www.economist.com/node/18290470> (access: 12.06.2013).

${ }^{25}$ In 2000 supporters of Al Ahly Benghazi football club spilled out into the town, burning pictures of the "Brotherly Leader"; see more L. Hilsum, Sandstorm. Libya in the time of revolution, New York 2012, pp. 1-39.

${ }^{26}$ Subsequently, Russia, China and South Africa criticised NATO's interpretation of the UN mandate as too transformative and synonymous to regime change. 
the National Transitional Council (NTC), as the legitimate government. A month later the NTC formally transferred powers to the General National Congress (GNC). Nevertheless, foreign intervention of 2011 was an attempt to "liberate" Libyans from their tyrant and to ignite liberal state-building. In fact, it prolonged civil strife as Qaddafi was able to easily put down the rebellion militarily and could have reformed Libya under his son and successor, Saif al-Islam. The humanitarian intervention nurtured the Arab Spring in the Libyan context and opened a Libyan Pandora's box. ${ }^{27}$ However, being already engaged on two counterinsurgency battlefield, the United States was not the main driver. Unsurprisingly, France and Britain and finally, NATO, took over command of operations in Libya. ${ }^{28}$ Leaving aside the moral justification, NATO air strikes were the coup de grâce for the staggering Qaddafi and laid the foundations for a new state to be born.

Thereafter, Libya's political and economic prospects can be depicted in three acts after Qaddafi. One could easily notice a lack of real democratic tradition with a plethora of challenges to post-Qaddafi Libya. Libya's history of divisions gave credence to Qaddafi's warnings in February 2011 that if he were ousted the country would disintegrate and Islamists would take over. Is this a real scenario? In contrast to Tunisia and Egypt Libya was a true revolution, that destroyed the entire apparatus of the state.

\section{LIBYA IN THREE ACTS AFTER 2011}

Libya's gradual stabilisation. Getting rid of a dictator is always much easier than building a political and constitutional order. Elections to the constituent assembly were to be held within 240 days after liberation and the plan envisaged 90 additional days to draft the new constitution. It was simply unrealistic given other transitioning states. ${ }^{29}$ Admittedly, Qaddafi's reign left Libya with arguably the weakest state institutions in the Maghreb as well as a limited sense of nationhood. On the other hand, some argue that it is better for a young democracy to build the state from scratch than to revive the remnants of a military regime. As many Libyans had studied abroad, attaining the technocratic skills of state-building, they could understand modernisation. Yet the Libyan civil war resulted in the contraction of its economy by 62 per cent in $2011 .{ }^{30}$ However, it rebounded by over $100 \%$

${ }^{27}$ The criticism of western intervention in Libya see: A. Kuperman, Obama's Libya Debacle How a Well-Meaning Intervention Ended in Failure, "Foreign Affairs" March/April 2015. According to the author NATO's intervention increased the death toll more than tenfold.

${ }^{28}$ The lion share of Libyan oil was exported to European markets (85\%). Yet, NATO's role was limited by an ambiguous stance of its members (with Germany abstained from the UNSC vote).

${ }^{29}$ C. S. Chivvis, J. Martini, Libya after Qaddafi. Lessons and implications for the Future, RAND 2014, p. 38.

${ }^{30}$ During the revolution, oil output decreased from 1,77 million barrels per day to a mere 22,000 barrels per day (July 2011). R. Al-Darwish, S. Cevik, J. Charap, S. George, B. Gracia, 
the following year. It is worth noticing that "stabilisation" does not necessarily mean exactly the same for interveners and Libyans, as the former officially saw Libya crisis in humanitarian terms. ${ }^{31}$ Unexpected calm in Tripoli directly after the war resulted in a very limited international posture in post-conflict Libya as the feeling of its promising start prevailed. ${ }^{32}$ What is more, the 2014 edition of the Global Peace Index (GPI) identified Libya as among three top risers (to a "medium peace" situation), but since then the condition has seriously deteriorated..$^{33}$

In July 2012 optimism about Libya reached the summit when the first elections since 1965 brought to power a moderate, secular coalition government with turnout estimated at 60 per cent. Apart from technical level, the elections did not create a stronger government given the highly fragmented parliament. As the result, new Libya's first prime minister survived less than one month in office. As of the moment of writing Libya has had seven prime ministers since March 2014 and a dispute over premiership between Abdullah al-Thinni and Khalifa Ghweil. To overcome this deadlock Libya needs to create a truly inclusive regime accepted by all tribes and provinces that offers access to state structures and divides the state's natural resources in a fair way. Wide acceptance of political and economic power distribution should be expected. Only then will state-design and allocation of money support further stabilisation. In May 2013 a new law banning Qaddafi-era officials from holding public office was enacted forcing the then prime minister to quit. The passage of this law resulted in the loss of some of Libya's most experienced bureaucrats and army officers, hindering administrative capacity and security sector reform. A year later the new government revoked this law but civil strife escalated. Since June 2014 the country has been split as the east is under the control of an internationally recognized secular government based in Tobruk (HOR) and Beida (Operation Dignity forces led by General Khalifa Haftar) and backed by Egypt and UAE. The west is controlled by the remnants of the Tripoli-based GNC backed by Islamist militias (so-called Libya Dawn military alliance), Sudan, Turkey and Qatar. ${ }^{34}$ Ghweil labelled them a "national salvation government".

S. Gray, S. Pattanayak, Libya Beyond the Revolution: Challenges and Opportunities, International Monetary Fund, Washington 2012, pp. 55-56.

${ }^{31}$ There is a vast literature on stability operations or so-called international state-building. See, among others, J. Dobbins et al., The Beginner's Guide to Nation-Building, RAND, Santa Monica 2007; Building states to build peace, ed. C. Call, V. Wyeth, London-Boulder 2008; Statebuilding and state-formation: the political sociology of intervention, ed. B. Bliesemann de Guevara, Abingdon-New York 2012.

${ }^{32}$ See e.g. D. Vandewalle, The Surprising Success of the New Libya, "Foreign Affairs" 2012, vol. 91, issue 6 .

${ }^{33}$ See Global Peace Index/Highlights, $<$ http://www.visionofhumanity.org/sites/default/files/ 2014\%20GPI\%20HIGHLIGHTS.pdf $>$ (access: 05.04.2015). The indicator measures three themes: the level security and safety in society, intensity of internal- or international conflict and the degree of militarisation.

${ }^{34}$ The HOR was declared unconstitutional by Libya's Supreme Court in November 2014. 
Consequently, today's Libya seems to suffer two different state-building projects and no functioning police or army. What is more, the end of Qaddafi left Libya with a plethora of armed militias (katibas) with different backgrounds, capabilities, and intentions. Under Qaddafi carrying weapons was banned but now almost everyone does it. In many regions and towns, during or shortly after the war, the rebel groups armed themselves and formed military councils that resembled some kind of localised authority. Many of them refused to disband but in general they did not fight each other except for skirmishes in Tripoli. Secondly, some of them were included in the Ministry of Interior's approach to absorb different revolutionary groups to a new Libyan state (the Supreme Security Committee). In fact, this is far from effective as they are still autonomous. ${ }^{35}$ As the result, in the spring of 2014 the United States postponed a plan to train a "general-purpose force" of about 15 thousand in the coming years.

Yet, unlike heavily populated Egypt, Libya has a population of just six million and considerable hydrocarbon reserves that could support its stability and state-building. ${ }^{36}$ Libyan reserves are estimated at almost 47,1 billion barrels (2010) with relatively low costs of oil production. ${ }^{37}$ The Sirte Basin Province with some forty huge oil fields accounts for about $80 \%$ of the country's proven oil reserves and $90 \%$ of its production (see Figure 2). This shows how crucial the need to rebuild infrastructure and to secure oil production will be in the future. Although oil production recovered to $85 \%$ of its pre-war volume, since secessionists seized control over eastern oil ports in the summer of 2013, output has averaged only to $30 \%$ of pre-war levels (approximately 160,000 barrels per day). That costs the Libyan government $\$ 130$ million per day in lost revenue. ${ }^{38}$ The central issue for Libya will be to maintain the neutrality of its crucial state institutions, i.e. Tripoli-based National Oil Corporation (NOC) and the Central Bank of Libya (CBL), which disburses government funds to both sides of the conflict. ${ }^{39}$ On the other hand, a "resource curse" argument undermines post-conflict reconstruction as it exempts the government from institutional development thus contributing to state failure or autocracy. In the near term, oil wealth also complicates demobilization and disarmament efforts as rebels expect well-paid state salaries that the new state cannot offer. Libya has to diversify its economy with the rise of tourism and oil services.

${ }^{35}$ C. S. Chivvis, J. Martini, op. cit., pp. 14-18.

${ }^{36}$ Oil accounts for approximately $95 \%$ of export earnings, $90 \%$ of government revenue and over $70 \%$ of GDP. See more R. Al-Darvish et al.

${ }^{37}$ Most of Libya remains unexplored due to the past sanctions.

${ }^{38}$ In November 2014 Libya's political strife escalated as a rival Tripoli-based government had seized a key oilfield in the west (El Sharara).

${ }^{39}$ The NOC accounts for $70 \%$ of Libya's oil output. 


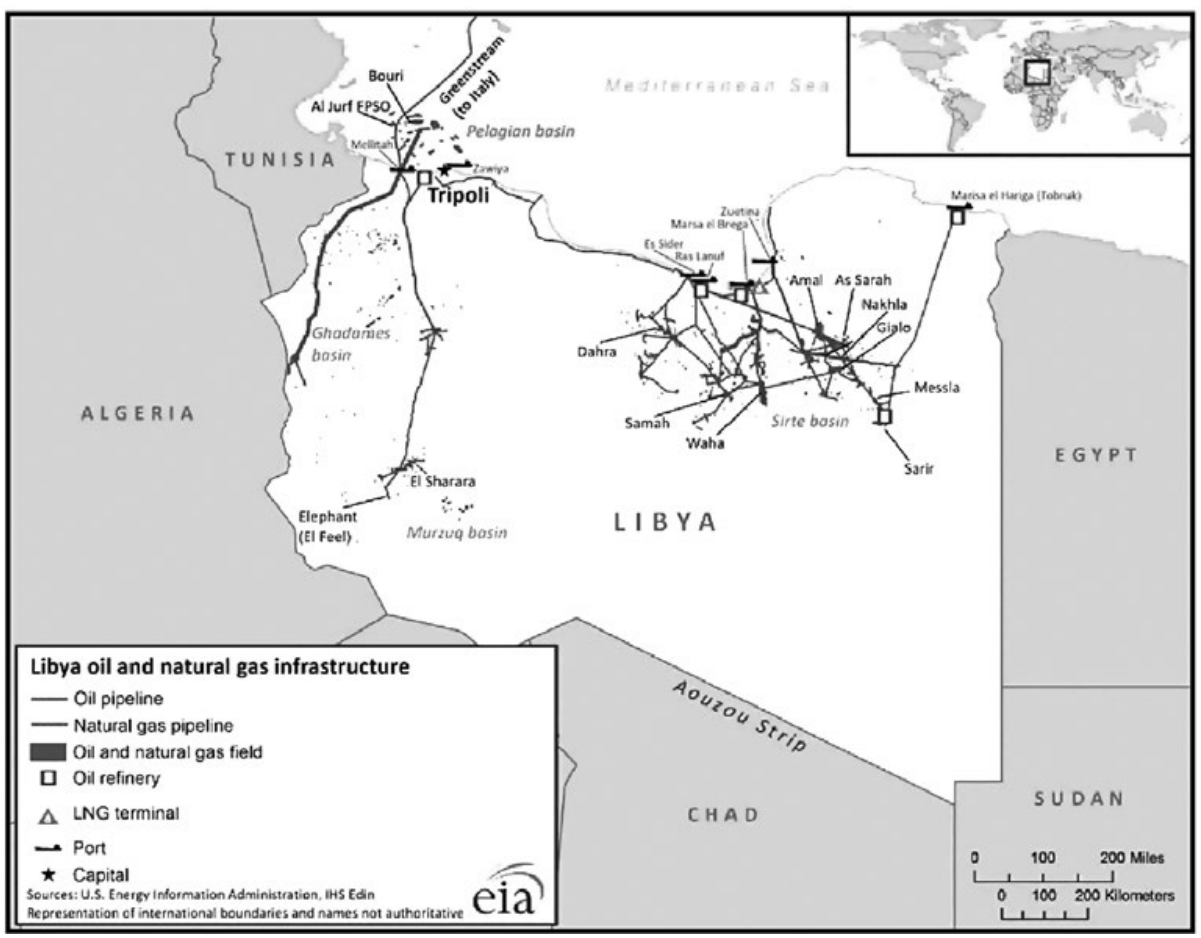

Fig. 2. Libya's energy infrastructure

Source: U.S. Energy Information Administration (September 2013).

In addition to this challenge, oil exports are under fiscal pressure because of volatile production and weak oil prices. Undoubtedly, Libyans should pay for the stabilisation scenario as much as possible, but international society should also contribute. The problem is that Libyan public administration is in very poor condition and probably any central government will have to face divisions and local resistance. Despite significant military and political engagement to change Qaddafi's regime, international actors have done little to date to support Libya's post-conflict stabilisation. In contrast to more robust multinational peace operations, both the UN's (UNSMIL ${ }^{40}$ ) and the EU's (EUBAM) missions are small and have no executive authority. ${ }^{41}$ A very limited role for the US and NATO cannot pave the way towards stability and security. However, at the beginning

${ }^{40}$ UNSMIL had been deployed in September 2011 and prolonged a few times, its current mandate was authorized by the UNSC resolution 2144 on 14 March 2014 to support the Libyan transition to democracy, promote the rule of law and human rights, control unsecured arms and build governance capacity. See more at $<\mathrm{http}$ ://unsmil.unmissions.org/unsmil.unmissions.org/Default.aspx?tabid $=3544 \&$ language $=$ en-US $>$ (access: 27.03 .2015$)$.

${ }^{41}$ However, in the autumn of 2011 Libyan authorities have feared that the deployment of peacekeeping forces would have ended up with "occupation" (like in Iraq) and eroded the NTC legitimacy; this resulted in the lack of invitation of such a mission. 
of 2015 international support has taken the form of UN-facilitated Geneva talks between two warring Libyan factions and rounds of political dialogue in Algeria and Morocco. ${ }^{42}$ Undoubtedly, with no international peacekeeping force, the best way to stabilise Libya is to engage Libyans in a national reconciliation process. In the short run some form of decentralisation that empowers tribes or regions and bonds them with the country may be necessary. This debate will focus on several issues. One of them concerns federal control over Libya's investment budget with a centralised or fixed, region-by-region approach.

Such an effort could give much needed security but needs to be inclusive. Apart from the legitimacy rift between two Libyan governments, it is hard to imagine any proper political settlement without Islamists at the table. UN peace brokers also need to engage military leaders of both sides but this had not originally happened. Thirdly, some representatives of local councils eager to consult should be invited to achieve a lasting solution. ${ }^{43}$ Talks could be supported by the impositions of oil sanctions on one side of the conflict but this would erase the neutrality of the UN or individual interveners and would only increase tensions that tend to further militarise Libyan affairs. Apart from these negotiations, given the regional security complex and the fragile situation in the Sahel, the central issue will be to reform Libya's security sector and to establish an effective, modern border-management system that is only possible with international assistance ${ }^{44}$ However, it will largely depend on political will of western donors much limited by the recent financial crises, post-conflict experience in Afghanistan and Iraq, and electoral calendars.

Apart from formal concerns, some observers also advocate deployment of a stabilisation force limited to Tripoli alone to deter conflict and defuse tensions. The main object of such a mission would be to stabilise the capital, support confidence-building measures between militias, and provide security for key infrastructure. It could also support security sector reform and conduct small-scale counterterrorism actions. This force would need 5,000-15,000 members. A second scenario would include stabilisation of other major cities along the Libyan coast (especially Benghazi but with a smaller presence in Misrata and Zintan) that should amount to 24,000 forces. Finally, a third solution would take the form of a nationwide stabilisation operation and would require about three times more members and an enormous logistical effort. ${ }^{45}$ Consequently, it could enable the Libyan government to "economise" local state-building. Any such effort would be politically risky, empowering spoilers, e.g., jihadists, opposed to Libya's stabilisation. That risk goes hand in hand with mission's size and capacity.

${ }^{42}$ The UN talks started in Ghadames in September 2014.

${ }^{43}$ See e.g. A. Kadlec, The Problem with Libya's peace talks, $<$ http://foreignpolicy.com/ 2015/01/16/the-problem-with-libyas-peace-talks/> (access: 14.03.2015).

${ }^{44}$ Apart from Qaddafi's guard units military forces were neglected under Qaddafi. See. C. S. Chivvis, J. Martini, op. cit., pp. 10-12, 84.

${ }^{45}$ Ibidem, pp. $72-74$. 
Jihadisation of Libya. The next two scenarios reflect the logic that the Arab Spring has only exposed the fragility of the Arab state. With a limited sense of nationhood and no visible international support, Libya's situation could easily deteriorate. Needless to say, Libyan tribes remain crucial to understanding local political dynamics, but the country's Muslim population and proximity to Europe attract various jihadist groups from North Africa and the Middle East. The risk of further radicalisation could finally lead to a "Somalisation" of Libya. However, according to the Armed Conflict Data \& Location Project, violence in the Libyan conflict has been decreasing since September 2014 (from about 1000 to $600 \mathrm{fa}$ talities per month on average); the only violence that is rising is that used by the Islamic State (IS) of Tripoli. This shows the declining role of political and ethnic militias and a more pragmatic approach. ${ }^{46}$

A loose Islamist front is emerging on the debris of Qaddafi. The September 11, 2012 killing of U.S. ambassador Christopher Stevens, has focused the world's attention on the problems of post-Qaddafi Libya. By May 2014 Libya was on the brink of a new war between moderates and Islamists. The latter include a mix of Salafists and Muslim Brothers, who appear to be more moderate and pragmatic in their dealing with non-Muslims and authority. The imams have started to take stands on political issues. Without national unity the Islamists have gained ground but are anything but monolithic. Some of them prefer a combination of religion with the modern state (and accepted the invitation to UN peace talks) but others abhor that idea and support the caliphate..$^{47}$ The point is to keep foreign jihadist out of Libya to avoid a second Afghanistan scenario. It will be possible with western assistance but any land operation could further strengthen jihadists and weaken the legitimacy of postwar political leaders. Libya has a strong jihadist tradition of the recent decade. Its jihadists have been a backbone of rebellion in Iraq, where Libyans made up 20 per cent of foreign extremists (virtually all from Cyrenaica, especially the port city of Darnah) and quite recently also in Syria. ${ }^{48}$

No group in Libya is immune from Islamism. Libyan Islamists has been externally driven by protracted wars in Iraq and Syria. Although Qaddafi stopped sponsoring terrorism even before September 11 2001, he did so due to the domestic threat from al-Qaeda-affiliated groups with Libyan Islamic Fighting Group. Since 2011 both Libya and Mali have turned into terrorist nests as jihadists, e.g. Ansar al-Sharia, recovered and refused to disarm after Qaddafi's fall ${ }^{49}$ All told,

${ }^{46}$ The project is directed by researchers from University of Sussex. Cf. ACLED. Conflict trends (no. 35) Real-time analysis of African political violence, March 2015, pp. 4-5, <http:// www.acleddata.com/wp-content/uploads/2015/03/ACLED-Conflict-Trends-Report-No.35March-2015.pdf $>$ (access: 13.04.2015).

${ }^{47}$ However, most Libyans believe political system should be shaped by Islam.

${ }^{48}$ This was indicated by the West Point's Combating Terrorism Center in 2008. A Libyan Bittar Brigade has fought alongside IS in Syria since 2011. Cf. C. S. Chivvis, J. Martini, op. cit., pp. 26-29.

${ }^{49}$ With the collapse of Qaddafi the ethnic Tuaregs of Mali - a backbone of his security forces fled home to launch their own rebellion and then subordinated to local jihadists' interests (Islamic state in northern Mali). 
this incubates the growth of radical Islam across the Maghreb and Sahel and equips them with weaponry. ${ }^{50}$ MI-6 estimated that there were a million tons of weaponry in Libya. ${ }^{51}$ With expansion of the Islamic State in the Maghreb with its Libya Dawn proxy, Libya's stability would be far more at risk. Moreover, anarchic Libya could serve as a transit point through which extremists could transfer to Europe under the guise of refugees. This threat will probably force the international community (and Egypt as it has already retaliated in February 2015 ) to act but short of a land operation. The Tobruk government would welcome these attacks. As of January 2015, factions aligned with ISIS have perpetrated killings in all three of Libya's traditional provinces and attacked oil fields. It has exploited Libya's chaos and attacked both warring sides.

On the other hand, this development could end up with some constructive shifts as the self-declared government in Tripoli feels so endangered by the IS that it begins to prioritize a unity government with the Tobruk administration. ${ }^{52}$ However, the rising influence of Islamists in eastern Libya could finally lead to the declaration of an emirate where jihadists could find a safe haven. Given that fact, an analogy with Syria and air strikes against conglomerate of jihadists should be taken into account. ${ }^{53}$ Finally, the Salafi-jihadist movement has been facing opposition from the Islamic sect of Sanusis. Similarly, the Abu Salim Martyrs Brigade, a local Salafi group, declined to support IS. As the Libya Dawn coalition continues to fall apart, the increased grip of Islamic State and Al-Qaeda affiliates may turn the plethora of Libya's Islamist armed groups against one another. Paradoxically, this inter-Islamists fighting could contribute to both Libya's stability and chaos. In 2015 the Islamic State has even expanded its foothold beyond the central coastal Libya (Sirte and Darnah). ${ }^{54}$ However, as ISIS has implemented its strict interpretation of Islam, prohibiting tobacco and forcing underage girls into marriage, it is still perceived as an outsider group with no or minimal local support in Libya (only 7 per cent of its population express a favourable view on ISIS in the Pew Research Centre survey from 2015). ${ }^{55}$

${ }^{50}$ Human Rights Watch estimated that the leakage of weapons from Qaddafi's regime was ten-fold higher and potentially more destructive (as it includes man portable air defense systems, MANPADs) than in Somalia, Afghanistan and Iraq. Cf. $<$ http://www.hrw.org/news/2011/10/25/ libya-transitional-council-failing-secure-weapons $>$ (access: 10.03.2015).

${ }^{51}$ C. S. Chivvis, J. Martini, op. cit., p. 8.

${ }^{52}$ Libya's new agony, "The Economist", <http://www.economist.com/news/middle-east-andafrica/21644195-descent-jihadist-chaos-forcing-neighbours-act-libyas-new-agony $>$ (access: 09.03. 2015).

${ }^{53}$ In December 2014, when asked if the camps of jihadists from IS in eastern Libya might be a target for US airstrikes, U.S. AFRICOM Commander General David Rodriguez said that "policy discussion is ongoing".

${ }^{54}$ According to estimates, the group has up to three thousand fighters in Libya.

${ }^{55}$ Surprisingly, it is viewed much better in neighbouring Tunisia (13 per cent) or in Malaysia (11 per cent). 
Fragmentation of Libya. Considering the acute civil strife could Libya fall apart? Immediately after the revolt of 2011, Saif al-Islam, the oldest son of Muammar Qaddafi warned Libyans of upcoming radicalization and the fragmentation of Libya into a dozen or so emirates if the uprising engulfed the entire country. ${ }^{56}$ Undoubtedly, in the past months Libya has been a place of gross human right violations that exacerbate regional divisions and the lack of trust. ${ }^{57}$ As of the moment of writing, territorial control over Libya is divided between local militias (Tuaregs in the west, Toubou in southern Fezzan), Libya Dawn (northern Tripolitania), the government in Tobruk (all of Cyrenaica and Zintan surroundings in the west), and Islamic State-affiliated groups, e.g., Ansar al-Sharia. Thus, this scenario stresses the factor of political, ideological and tribal fighting over power as the second civil war erupted in the middle of 2014 and the new actors which emerged in such security vacuum..$^{58}$ The creation of Libya Dawn, a loose coalition in Misrata, was aimed at countering anti-revolutionary and anti-Islamic forces led by Qaddafi-era military officer Khalifa Haftar. This made its initial success relatively easy as local proxies in the west had aligned with Libya Dawn and targeted Haftar's allies in the west (Zintani Brigades and Wershefana tribal militias). The GNC conglomerate seems to be united by the fear of an Egypt-like military dictatorship.

However, the split between hardliners in the GNC and more moderate Misrata has widened in recent months. The latter seemed to want a political solution in the spring of 2015 to promote its own cause. This could easily obstruct Misrata's crucial financial and military support for the GNC. Haftar's Libyan National Army wants to eradicate all Islamists regardless of their affiliation. He is a divisive figure even within the Tobruk government. ${ }^{59}$ Even with the coalition's focus against Haftar waning, a conflict between regional and local interests may follow. If the country were to be unstable for an extended period of time, tribes provide the best protection against weak government and Libya fragmenting. The stalemate in the UN talks makes this scenario more probable. Anas el-Gomati, director of Libyan think-tank the Sadeq Institute calls the UN talks into question as many Libyan forces fight for regional objectives and economic survival of their own region, not for Libya Dawn or Libya Dignity, which makes Libya's future more knotty. ${ }^{60}$

$56<\mathrm{http}: / /$ www.alarabiya.net/articles/2011/02/21/138515.html $>$ (access: 08.11.2014).

${ }^{57}$ According to the Dignity - Danish Institute against Torture the current conflict has left a third of Libyans with mental health problems; only 2 per cent of respondents reported being helped by NGOs (this survey was completed in October and based on nearly 3 thousand households), <http:// www.theguardian.com/world/2014/nov/26/human-rights-abuses-libyans-mental-health-problems-report> (access: 12.03.2015).

${ }^{58}$ In contrast to the previously mentioned GPI indicator the Fund for Peace's Fragile States Index 2014 (FSI) assessed Libya among three top worsened situations in 2013 (cf. footnote 29).

${ }^{59} \mathrm{He}$ was accused of organising a coup d'état on Valentine Day in 2014. However, according to observers, there were no single "état " that could have been overthrown.

${ }^{60}<\mathrm{http}$ //www.aljazeera.com/news/2015/04/libya-win-war-150419073028848.html > (access: 20.04.2015). 
The prolonged stalemate and chaos will force both sides to find clashing sources of legitimacy and income as the HOR government in Tobruk tries to sell oil separately because this had built up legitimacy of the NTC in 2011. This could lead to the demise of the current Libyan state and the emergence of an Islamic caliphate and separate and warring Tobruk and Tripoli aspirations for statehood emerging.

There is also another traditional player. The federalist movement led by sheikh Zubayr as-Sanusi - a descendant of former king Idris - which calls for autonomy of Cyrenaica (Barqa in Arabic). His supporters were disappointed by the political and economic marginalisation of eastern Libya after the country had been unified, and some factions boycotted consecutive elections due to their too small representation in the national assembly. The region in less populous than Tripolitania but far richer as hydrocarbon reserves and gas and oil infrastructure are predominantly located in the eastern Sirte basin (80\%), while the only oilfield in western Libya is in Fezzan. As a result, the three regions are doomed to cooperate. It is worth noting that the Barqa Council's goal is not to utterly secede from Libya, but the movement has evolved in recent months with the stronger footing of jihadists. However, in spring of 2015 the GNC was becoming more moderate, while al-Thinni (HOR) has to face many hardliners on his side eager to militarise state-building. ${ }^{61}$ Some of them want to the restore monarchy. Generally speaking, the climate of religious conservatism in eastern Libya makes it easier for the militants to operate.

For some observers post-intervention Libya has simply become a militia state. The state which is awash with rival militia groups: islamist militias (Libya Dawn, Libya Shield and other pro-GNC forces), jihadists (Islamic State, Ansar al-Sharia) or pro-government groups representing the HOR. Therefore, today's Libya is characterised by the distinct militant dynamics in its western, central or eastern part that in fact have split the country apart.

\section{CONCLUDING REMARKS}

Today's Libya is no longer the same, as Qaddafi reign changed its social fabric and western intervention has not answered many questions. As Qaddafi's primordial instruments of stabilisation has passed the lack of modernization will result in the next tyranny or chaos. The problem is that post-Qaddafi Libya has never really experienced a period of peace and is now captured by plethora of militias which are not integrated into the state. Conversely, it was the Libyan state which has been integrated into the militias. However, the current narrative in Libya goes beyond a simple Islamist - non-Islamist division. It seems to encompass inter-Islamist splits amongst Islamist State, AQIM, the Muslim Broth-

${ }^{61}$ Finally, in August 2015 al-Thinni decided to step down due to criticism about his cabinet ineffectiveness in eastern Libya. 
erhood, moderate Islamists, and hardliners. Secondly, it involves revolutionary versus counter-revolutionary semantics and Bedouin - non-Bedouin provenance. Thirdly, relationships between the various stakeholders of Libya's stabilisation are constantly in flux. As long as the future of Libya is treated as a zero-sum game by its warring factions of differing orientations, the situation could only deteriorate. It is not in the interest of either Libyans or the international community to have Libya fragmented as the international community (buyers) wants to know who is a legitimate government (oil seller) in Libya. As Libya's rebound in oil output contributed to a near 30 per cent drop in oil prices in the second half of 2014, these developments could also divide the world's biggest producers and consumers. Each fragmentation of Libya could sooner or later stand for a failure and the beginning of the next crisis in the Maghreb and Sahel region (e.g. Mali).

In the long run Libya's stability and unity seems to be hostage to oil production and inclusive state-building with concerted assistance from international actors who fear the spread of jihadism. The latter could lead to a stronger UN peacekeeping operation aiming at disarmament, demobilization, and reintegration (DDR) of rebel forces or takes the form of UN Peace Building Commission assistance in Libya. Prospectively, a new conference on Libya is needed to build a government of national unity to avert Jihadisation or state collapse that would be damaging for the West. The alternative is a really enduring conflict. Thus, the success of the third experiment with Libyan statehood requires a combination of modernizers, Islamists, decentralization, and external support. However, most countries haven't taken sides and prefer UN peace talks though they have some distinct interests, e.g., France primarily wants stability in southern Libya that preserves peace in northern Mali. The United States perceives Libya through the lens of a prospective Islamic State foothold, and many others prioritize energy security. However, what they should have in common about post-Qaddafi Libya is to support its state-building overseas (training of Libyan security forces) and on the ground (expertise, policing) with balanced tribal and regional representation. The goal also needs to be realized in cooperation with the Gulf Cooperation Council and Arab League that helped to topple Qaddafi. Undoubtedly, it won't be an easy task to break the current political deadlock and then build a modern state in Libya. The long-awaited December 2015 accord to form the government of national reconciliation could be a harbinger of the right direction. One that has been necessitated by the rising ISIS threat in the region.

\section{PERSPEKTYWY (DE)STABILIZACJI LIBII PO KONFLIKCIE}

Strzeszczenie. Wraz z wydarzeniami arabskiej wiosny niektóre reżimy z basenu Morza Śródziemnego zostały zmuszone do reform lub obalone i zastąpione przez opozycję demokratyczną. Spośród kilku przykładów takiej rewolucji Libia jawi się jako przypadek szczególny. Osobliwości systemu zbudowanego przez Muammara Kaddafiego, sponsorowane dochodami z eksploatacji złóż ropy, skutkowały destrukcją struktur państwa i nasileniem trybalizmu. Rewolucja z 2011 r. 
zmieniła wprawdzie konstrukcję polityczną Libii, lecz nie mogła przekreślić minionych dekad neopatrymonialnych i represyjnych rządów. Sam kres reżimu Kaddafiego nie jest zatem przesłanką pokoju po konflikcie, a Libia musi uprawomocnić swoją transformację i wypracować narodowy konsensus. W artykule analizowane są trzy scenariusze rozwoju sytuacji (stopniowa stabilizacja, „dżihadyzacja” oraz defragmentacja) w pokonfliktowej Libii. Celem autora jest rozważenie ich prawdopodobieństwa z uwzględnieniem splotu specyfiki wewnętrznej oraz sytuacji międzynarodowej.

Słowa kluczowe: Libia po 2011 r., upadek państwa, budowanie państwa, Państwo Islamskie 